\title{
The Binding of Some Human Antiendothelial Cell Antibodies Induces Endothelial Cell Apoptosis
}

\author{
Anne Bordron, ${ }^{\star}$ Maryvonne Dueymes, ${ }^{*}$ Yair Levy, ${ }^{\ddagger}$ Christophe Jamin, ${ }^{\star}$ Jean-Paul Leroy, ${ }^{\star}$ Jean-Charles Piette, ${ }^{\S}$ \\ Yehuda Shoenfeld, ${ }^{\ddagger}$ and Pierre Y. Youinou* \\ *Laboratory of Immunology, “Institut de Synergie des Sciences et de la Santé,” Brest University Medical School, F 29609 Brest, France; \\ ${ }^{\ddagger}$ Department of Medicine B, Research Unit of Autoimmune Diseases, Chaim Sheba Medical Center, Tel-Hashomer, 52621 Israel; and \\ ${ }^{\S}$ Department of Internal Medicine, La Pitié-Salpétrière Hospital, 75651 Paris, France
}

\begin{abstract}
The pathogenic role of antiendothelial cell antibodies (AECA) remains unclear. They are frequently associated with antibodies to anionic phospholipids (PL), such as phosphatidylserine (PS), which is difficult to reconcile with the distribution of PL molecular species within the plasma membrane. Since it is already known that PS is transferred to the outer face of the membrane as a preclude to apoptosis, the possibility exists that apoptosis is initiated by AECA. AECA-positive/anti-PL antibody-negative sera from eight patients with systemic sclerosis (SS) and 21 control patients were evaluated. Endothelial cells (EC) were incubated with AECA and the exposure of PS was established through the binding of annexin V. Hypoploid cell enumeration, DNA fragmentation, and optical and ultrastructural analyses of EC were used to confirm apoptosis. Incubation of EC with AECA derived from six of eight patients with SS led to the expression of PS on the surface of the cells. This phenomenon was significantly more frequent in SS $(P<0.04)$ than in control diseases. The redistribution of plasma membrane PS preceded other events associated with apoptosis: hypoploidy, DNA fragmentation, and morphology characteristic for apoptosis. Apoptosis-inducing AECA did not recognize the Fas receptor. We conclude that AECA may be pathogenic by inducing apoptosis. (J. Clin. Invest. 1998. 101:2029-2035.) Key words: endothelial cells • antiendothelial cell antibody $\bullet$ apoptosis
\end{abstract}

\section{Introduction}

Antiendothelial cell antibodies (AECA) ${ }^{1}$ were first described by fluorescence analysis and subsequently characterized using purified $\operatorname{IgG}$ and $\mathrm{F}\left(\mathrm{ab}^{\prime}\right)_{2}$ fragments (1). These autoantibodies

Address correspondence to Pierre Y. Youinou, Laboratory of Immunology, Brest University Medical School Hospital, BP 824, F 29609 Brest, Cedex, France. Phone: 33-2-98-22-33-84; FAX: 33-2-98-80-1076 or 33-2-98-22-38-47; E-mail: youinou@univ-brest.fr

Received for publication 13 November 1997 and accepted in revised form 2 March 1998.

J. Clin. Invest.

(C) The American Society for Clinical Investigation, Inc. 0021-9738/98/05/2029/07 \$2.00

Volume 101, Number 10, May 1998, 2029-2035

http://www.jci.org
(Ab) have since been reported in a variety of clinical settings associated with vasculitis (2), such as systemic sclerosis (SS). Although the results obtained in a given disease vary from one study to another (3), the AECA test shows promise as a sensitive indicator of endothelial cell (EC) injury (4). In fact, AE$\mathrm{CAs}$ represent an extremely heterogeneous family of $\mathrm{Ab}$ reacting with different structures on EC (5), the effects of which remain to be defined.

The recent finding that EC apoptosis, i.e., programmed cell death, is a primary pathogenic event underlying skin lesions in avian and human SS (6) may be highly relevant to our study on the pathogenesis of AECA because we have reported recently that SS is associated with AECA (7). It is not unreasonable to predict that a subgroup of AECA might recognize surface antigens $(\mathrm{Ag})$ involved in apoptosis. Since it is known that phosphatidylserine (PS) is transferred to the outer face of the membrane as a preclude to apoptosis (8), the possibility exists that this movement of PS is initiated by AECA. It was also shown that the anticoagulant $\alpha$, i.e., annexin $\mathrm{V}$, preferentially binds to negatively charged phospholipids (PL) like PS (9).

The major thrust of this study was, therefore, to explore the effects of AECA on the surface of EC. We report the first evidence that AECAs are capable, not only of inducing expression of adhesion molecule (10) and sustaining leukocyte adhesion to vascular EC (11), but also of initiating apoptosis of the cells and thereby exposing anionic PL. The exposure of PS on EC by AECA may be important in triggering the production of antiphospholipid $\mathrm{Ab}(\mathrm{aPL})$ in connective tissue diseases.

\section{Methods}

\section{Polyclonal and monoclonal antibodies}

Previously, AECA had been found to be present in 42 of 67 patients with SS (7). Of these, eight were selected on the basis of high level of AECA and absence of aPL (patients 1-8). Their AECA-positive/ aPL-negative serum was collected again after appropriate consent was obtained and the study approved by the Institutional Review Board. All eight patients fulfilled the 1982 criteria of the American

1. Abbreviations used in this paper: $\mathrm{Ab}$, antibody; $\mathrm{Ag}$, antigen; AECA, antiendothelial cell antibody; aPL, antiphospholipid antibody; $\beta_{2}$ GPI, $\beta_{2}$-glycoprotein I; CL, cardiolipin; EC, endothelial cell; Fc $\gamma$ R, Fc $\gamma$ receptor; GTA, glutaraldehyde; HUVEC, human umbilical vein endothelial cells; MFI, mean fluorescence intensity; PFA, paraformaldehyde; PI, propidium iodine; PL, phospholipid; PS, phosphatidylserine; RT, room temperature; SS, systemic sclerosis; TM, thrombomodulin. 
College of Rheumatology for the diagnosis of SS (12). Patients with other diseases were included as controls in the study (4): 5 of 26 cases of giant cell arteritis, 5 of 32 with polyarteritis nodosa, 3 of 21 with Takayasu arteritis, 3 of 51 with Wegener's granulomatosis, and 5 of 20 with SLE were selected for further study on the same two criteria as the patients with SS. All fulfilled the ACR criteria for the respective diseases (13-17). Sera were stored at $-70^{\circ} \mathrm{C}$ until used. To remove any contaminating aPL, the sera from all the patients were passed through a column of cardiolipin (CL). A mixture of CL (Sigma Chemical Co., St. Louis, MO), dicetylphosphate (Sigma Chemical Co.) and cholesterol (BDH Chemicals, Poole, United Kingdom) was immobilized on a matrix of acrylamide-bis-acrylamide (Bio-Rad, Ivry-sur-Seine, France), and polymerized in the presence of ammonium persulphate and TEMED. The flow-through sera were collected and dialyzed against PBS (SS patients: effluents 1-8). IgG fractions were further purified with protein G-Sepharose (Pharmacia Fine Chemicals, Uppsala, Sweden) and recovered with HCl-glycine (SS patients: eluates 1-8). SDS-PAGE, Western blotting, and ELISA showed only $\operatorname{IgG}$ to be present.

$\mathrm{IgG}$ from five patients with SS were digested by incubation with pepsin (Sigma Chemical Co.) for $16 \mathrm{~h}$ at $37^{\circ} \mathrm{C}(40: 1, \mathrm{wt} / \mathrm{wt})$. The $\mathrm{F}\left(\mathrm{ab}^{\prime}\right)_{2}$ fragments were passed over a protein $\mathrm{G}$ column, concentrated, dialyzed extensively, and assayed using a sandwich ELISA.

Unconjugated mouse $\mathrm{mAb}$ against platelet/EC adhesion molecule (CD31, clone JC/70A) and against protein S (clone HS-3) were obtained from DAKOPATTS (Glostrup, Denmark) and Sigma Chemical Co., respectively. Anti-intercellular adhesion molecule-1 (CD54, clone 84H10), antilymphocyte function-associated $\mathrm{Ag}-3$ (CD58, clone AICD 58), antiglycolipid ceramide trihexoside (CD77, clone 38/13), antivascular cell adhesion molecule (CD106, clone 1G11), and anti-MHC class I molecule (clone B912-1) mAb were all supplied by Immunotech (Marseille, France). Three anti-Fas mAb (CD95, clones UB2, CH11 and ZB4) and three anti-Fcy receptor (Fc $\gamma$ R) mAb (CD16, Fc $\gamma$ RIII, clone 3G8; CD32, Fc $\gamma$ RII, clone 2E1; and CD64, Fc $\gamma$ RI, clone 22) were also obtained from Immunotech.

Unconjugated mouse $\mathrm{mAb}$ to $\beta_{2}$ glycoprotein I ( $\left.\beta_{2} \mathrm{GPI}\right)$ and antithrombomodulin (TM) rabbit $\mathrm{Ab}$ were kindly donated by Dr. J. Arvieux (Centre de Transfusion Sanguine, Grenoble, France) and Dr. M.C. Boffa (INSERM U353, Paris, France), respectively.

\section{Other reagents}

The anticoagulant $\alpha$ (annexin $\mathrm{V}$ ), has been shown to bind preferentially to PS (9). FITC-conjugated annexin V (generous gift of Dr. C.P.M. Reutelingsperger, Maastricht, The Netherlands) was, therefore, used to detect PS expression on EC. Normal IgG were eluted from a protein $\mathrm{G}$ column loaded with human or rabbit Cohn fraction II (Sigma Chemical Co.) and suspended in PBS. Human and rabbit IgG was aggregated by heating IgG at $63^{\circ} \mathrm{C}$ for $20 \mathrm{~min}$. IFN $\gamma$ was supplied by Genzyme (Cambridge, MA).

\section{Human umbilical vein endothelial cells}

Human umbilical vein endothelial cells (HUVEC) were isolated as described previously (18), and their viability was always over $95 \%$ as assessed by the acridine orange/ethidium bromide technique. These cells were cultured in RPMI 1640 (GIBCO, Paisley, Scotland) supplemented with $10 \%$ FCS.

\section{AutoAb tests}

The AECA test was performed as described previously $(4,7)$, but, in this case, HUVEC were used as a substrate, instead of the EA.hy 926 EC line. Briefly, cells were plated onto fibronectin-coated 96-well microtiter plates (Nunc A/S, Roskilde, Denmark), and allowed to grow to confluence. HUVEC were used at the third passage, and fixed with $0.1 \%$ glutaraldehyde (GTA) for $10 \mathrm{~min}$ at $4^{\circ} \mathrm{C}$. They were monitored by phase contrast microscopy to ensure confluence throughout the procedure. Nonspecific binding was blocked for $2 \mathrm{~h}$ at room temperature (RT) with $200 \mu \mathrm{l}$ RPMI 1640 supplemented with 3\% BSA. After two washes with PBS containing 1\% BSA (PBS-BSA), the wells were flooded with $100 \mu \mathrm{l}$ of the coded sera (diluted 1:50) in triplicate. After another three washes with PBS-BSA, horseradish peroxidaseconjugated goat $\mathrm{F}\left(\mathrm{ab}^{\prime}\right)_{2}$ anti-human IgG or anti-mouse IgG (Jackson ImmunoResearch Labs, Inc., West Grove, PA) was added and incubated for $1 \mathrm{~h}$ at $37^{\circ} \mathrm{C}$. After washing, the plates were developed with 1,2 phenylethylenediamine, the reaction was stopped with sulfuric acid, and the OD was read in a Titertek Multiskan microplate reader (Flow Laboratories, McLean, VA). Standard curves were established with internal reference positive sera. Samples were recorded as positive if the OD was greater than the mean plus three SD of that determined in 27 normal sera.

The IgG-specific ELISA for aPL has also been described previously in detail (19). In the conventional assay $\left(\beta_{2}\right.$ GPI-dependent aPL), nonspecific binding of Ig to the well surface was blocked with $200 \mu$ l of PBS containing 10\% adult bovine serum (Sigma Chemical Co.). A modified ELISA to detect $\beta_{2}$ GPI-independent aPL was also performed by using $0.3 \%$ gelatin (Sigma Chemical Co.) as the blocking agent and sample diluent. Binding of each sample on wells with no $\mathrm{Ag}$ was automatically substracted.

As reported previously (19), an ELISA was set up to assay $\beta_{2}$ GPI. This is based on the combination of a rabbit $A b$ as capture agent and a mAb anti- $\beta_{2}$ GPI as revealing agent. The standard curve was constructed with serial dilutions of pure $\beta_{2}$ GPI (generous gift of Pr S.A. Krilis, Sydney, Australia).

\section{Flow cytometric analysis}

Fresh EC were incubated with saturating amounts of FITC-conjugated $\mathrm{mAb}$ to $\mathrm{CD} 16, \mathrm{CD} 32, \mathrm{CD} 64$, or $\mathrm{CD} 95$ for $30 \mathrm{~min}$ at $4^{\circ} \mathrm{C}$. After washing with $\mathrm{PBS}$, they were fixed with $1 \%$ paraformaldehyde. FITC-conjugated irrelevant mouse $\operatorname{IgG} 1$ or $\operatorname{IgG} 2 \mathrm{a}$ mAb were used as negative controls.

Once they were stained, $5 \times 10^{5}$ HUVEC were suspended in PBS-BSA containing $0.02 \% \mathrm{NaN}_{3}$. After passage through a nylonmesh filter, EC were enumerated in a flow cytometer (Coulter Immunology, Hialeah, FL) equipped with a $500 \mathrm{~mW}$ argon laser and a helium-neon laser. Appropriate settings of forward and side scatter gates were used to examine 10,000 cells per experiment. These settings selected were controlled by using unstained cells and isotypematched nonreactive phyco-erythrin- or FITC-conjugated mAb. The percentages of cells stained were determined by the thresholds set using the unstained cells. The numbers of fluorescent molecules per cell were indirectly measured by assessing the mean fluorescence intensity (MFI) of cells analyzed in each test.

\section{Measurement of apoptosis}

BINDING OF ANNEXIN V

Simple staining. Fresh EC were washed in annexin V buffer $(20 \mathrm{mM}$ Hepes/NaOH, pH 7.4, $132 \mathrm{mM} \mathrm{NaCl}, 6 \mathrm{mM} \mathrm{KCl}, 2.5 \mathrm{mM} \mathrm{CaCl}_{2}, 1 \mathrm{mM}$ $\mathrm{MgSO}_{4}, 1.2 \mathrm{mM} \mathrm{KH} \mathrm{PO}_{4}, 5 \mathrm{mM}$ glucose, and $0.5 \%$ BSA). EC $\left(10^{5}\right.$ cells per test) were then incubated in $250 \mu \mathrm{l}$ of the same buffer containing $25 \mathrm{ng} / \mathrm{ml}$ FITC-conjugated annexin $\mathrm{V}$ for $10 \mathrm{~min}$ at $\mathrm{RT}$ in the dark. Propidium iodide (PI) was used to exclude dead cells, diluted to the concentration of $10 \mu \mathrm{g} / \mathrm{ml}$. Percentages of annexin V-positive cells were then calculated within the viable population of cells (i.e., PI-negative cells).

The effect of the dose of AECA on EC was tested using 0, 2.5, 5, 10 , and $20 \mu \mathrm{g}$ over a constant period of time $(360 \mathrm{~min})$. A time course was determined, using a constant amount of human or mouse $\mathrm{Ab}$ (20 $\mu \mathrm{g})$ for increasing periods of time $(0,60,120,180,360$, and $720 \mathrm{~min})$.

Double staining. A combination of reagents was tested: $100 \mu \mathrm{l}$ of fresh EC suspension were mixed with AECA or control IgG. After a 30-min incubation at $4^{\circ} \mathrm{C}$ and four washes (two in PBS-BSA and two in annexin $\mathrm{V}$ buffer), the cells were stained with phyco-erythrin-conjugated goat anti-human IgG Ab (DAKOPATTS) for 30 min at $4^{\circ} \mathrm{C}$. FITC-conjugated annexin $\mathrm{V}$ was added $10 \mathrm{~min}$ before the end of this incubation. 
Table I. Binding of FITC-conjugated Annexin V to EC Incubated with Anti-EC IgG from Eight Patients with SS

\begin{tabular}{lcc}
\hline & \multicolumn{2}{c}{ Staining with FITC-annexin V } \\
\cline { 2 - 3 } IgG used to stimulate EC & Percent of stained cells & MFI \\
\hline Patient 1 & 46 & 1.71 \\
Patient 2 & 52 & 1.80 \\
Patient 3 & 43 & 1.59 \\
Patient 4 & 44 & 1.34 \\
Patient 5 & 30 & 1.42 \\
Patient 6 & 19 & 0.99 \\
Patient 7 & 14 & 0.87 \\
Patient 8 & 27 & 0.97 \\
Control IgG & 12 & 0.91 \\
Medium & 14 & 1.12 \\
& & \\
\hline
\end{tabular}

ENUMERATION OF HYPOPLOID CELLS

After treatment of the cells with AECA, apoptosis was determined using the technique described by Nicoletti et al. (20). Briefly, a first aliquot of the cell preparation was stained with FITC-conjugated annexin V. A second aliquot of cells was washed in citrate buffer $(0.1 \mathrm{M}$ sodium citrate, $0.1 \%$ Triton $\mathrm{X}-100)$ and incubated in $250 \mu \mathrm{l}$ citrate buffer containing $10 \mu \mathrm{g} / \mathrm{ml}$ PI overnight at $4^{\circ} \mathrm{C}$ in the dark. Reduction in PI staining intensity compared with control cells by flow cytometry was taken as a measure of hypoploidy, characteristic of apoptotic cells.

\section{DNA FRAGMENTATION ANALYSIS}

EC were washed three times in HBSS (Eurobio, Les Ulis, France) and once in lysis buffer (250 mM sucrose, $50 \mathrm{mM}$ Tris, $\mathrm{pH} 7.5,25 \mathrm{mM}$ $\mathrm{KCl}$, and $5 \mathrm{mM} \mathrm{MgCl}_{2}$ ). Cell pellets were resuspended and incubated for $8 \mathrm{~min}$ on ice in a solution of $0.25 \%$ Triton X-100 (Sigma Chemical Co.) added to $500 \mu \mathrm{l}$ lysis buffer. After centrifugation for $5 \mathrm{~min}$ at $500 \mathrm{~g}$ and $4^{\circ} \mathrm{C}$, nuclei were resuspended in 500-ml lysis buffer supplemented with $25 \mu \mathrm{l} 0.5 \mathrm{M}$ EDTA, $70 \mu \mathrm{l} 10 \% \mathrm{SDS}$, and $0.2 \mathrm{mg}$ proteinase $\mathrm{K}$ (all from Sigma Chemical Co.), and incubated for $3 \mathrm{~h}$ at $37^{\circ} \mathrm{C}$. The DNA was extracted with phenol/chloroform/isoamyl alcohol (25:24:1) followed by two extractions with chloroform (vol/vol). After $5 \mathrm{~min}$ of washing at $400 \mathrm{~g}$ and $4^{\circ} \mathrm{C}$, a 1:10 vol of sodium acetate followed by 2 vol of absolute ethanol were added. DNA was kept for $12 \mathrm{~h}$ at $4^{\circ} \mathrm{C}$ and centrifuged for $10 \mathrm{~min}$ at $450 \mathrm{~g}$. $2 \mathrm{vol}$ of absolute ethanol were then added before centrifugation and addition of $70 \%$ ethanol. DNA was dissolved in $10 \mathrm{mM}$ Tris, $\mathrm{pH} \mathrm{7.5,} \mathrm{and} 1 \mathrm{mM}$ EDTA, $\mathrm{pH}$ 8, for $12 \mathrm{~h}$ after evaporation of ethanol. The DNA was loaded into wells of a $1.5 \%$ agarose gel and electrophoresed at $75 \mathrm{mV}$ using $100 \mathrm{mM}$ Tris, $100 \mathrm{mM}$ boric acid, and $0.2 \mathrm{mM}$ EDTA as running buffer. DNA was visualized by ethidium bromide staining.
Table III. AECA and Apoptosis-inducing AECA in Connective Tissue Disease

\begin{tabular}{lccccccc}
\hline & \multicolumn{7}{c}{ Number positive/number tested (percent positive) } \\
\cline { 2 - 7 } & SS & GCA & PAN & TA & WG & SLE & NC \\
\hline \multirow{2}{*}{ AECA } & $42 / 67 *$ & $8 / 26$ & $10 / 32$ & $7 / 21$ & $7 / 51$ & $9 / 20$ & $1 / 27$ \\
& $(62.7)$ & $(30.8)$ & $(31.2)$ & $(33.3)$ & $(13.7)$ & $(45.0)$ & $(2.9)$ \\
Apoptosis-inducing & $6 / 8^{*}$ & $2 / 5$ & $1 / 5$ & $1 / 3$ & $0 / 3$ & $1 / 5$ & $0 / 10$ \\
AECA & $(75.0)$ & $(40.0)$ & $(20.0)$ & $(33.3)$ & $(0.0)$ & $(20.0)$ & $(0.0)$
\end{tabular}

*SS compared with control diseases, $P<10^{-6} ;{ }^{\ddagger} \mathrm{SS}$ compared with control diseases, $P<0.04$. $G C A$, giant cell arteritis; $P A N$, polyarteritis nodosa; $T A$, Takayasu arteritis; $W G$, Wegener's granulomatosis; $N C$, normal control.

\section{CELL MORPHOLOGY}

$10^{5}$ control and apoptotic EC were centrifuged for 1 min at $300 \mathrm{~g}$ on a microscope slide. The slides were dried in air for $10 \mathrm{~min}$, and the cells stained in a May-Grünwald solution (Merck, Darmstadt, Germany) for $3 \mathrm{~min}$, washed in water for $1 \mathrm{~min}$, stained in a Giemsa solution (Merck) $7 \%$ in distilled water, and finally rinsed in water before analysis.

\section{ELECTRON MICROSCOPY}

The cells were fixed for $1 \mathrm{~h}$ at RT in $3 \%$ GTA in PBS, post-fixed with $1 \% \mathrm{OsO}_{4}$ in $\mathrm{PBS}$, and incubated overnight at $60^{\circ} \mathrm{C}$ with $2 \%$ uranyl acetate in water. This was followed by rapid dehydration with increasing concentration of absolute alcohol and a 1-h incubation in a 1:1 absolute ethanol/Epon mixture. Cells were embedded in Epon and, after sectioning and staining, viewed in a Zeiss EM 10 electron microscope (Carl Zeiss Instruments, Oberkichen, Germany).

\section{Results}

Effect of AECA on the expression of anionic PL by EC. Incubation of EC with $20 \mu \mathrm{g}$ AECA for $5 \mathrm{~h}$ led to the expression of negatively-charged PL by the cells. This effect was demonstrated by the binding of annexin V. AECA IgG from SS patients $1,2,3,4,5$, and 8 induced the expression of surface PS (Table I), compared with control Ab. In contrast, AECA IgG from SS patients 6 and 7 gave similar binding levels to that of the control IgG. Treatment with $7 \mathrm{mAb}$ directed to various $\mathrm{Ag}$ on EC and anti-TM rabbit $\mathrm{Ab}$ (Table II) failed to induce annexin $\mathrm{V}$ binding, which suggested that the effects of AECA were specific. A slightly high percentage of stained cells after incubation with antiglycolipid ceramide trihexoside $(8 \%)$ was, however, observed. This is consistent with the report (21) that

Table II. Binding of FITC-conjugated Annexin V to EC Incubated with Control Ab

\begin{tabular}{lcccccccc}
\hline & \multicolumn{7}{c}{ Ab used to stimulate EC } \\
\hline Staining with FITC-annexin V & PECAM* & Protein S & ICAM-1 & LFA-3 & GCT & VCAM-1 & MHC class I & TM \\
Percent of stained cells & 2 & 5 & 3 & 1 & 8 & 2 & 2 \\
MFI & 1.70 & 0.82 & 0.93 & 1.31 & 1.12 & 0.73 & 0.84 \\
& & & & & & & & \\
\hline
\end{tabular}

*PECAM, Platelet/EC adhesion molecule; ICAM-1, intercellular adhesion molecule-1; LFA-3, leukocyte function-associated antigen-3; GCT, glycolipid ceramide trihexoside; $V C A M-1$, vascular cell adhesion molecule-1. 

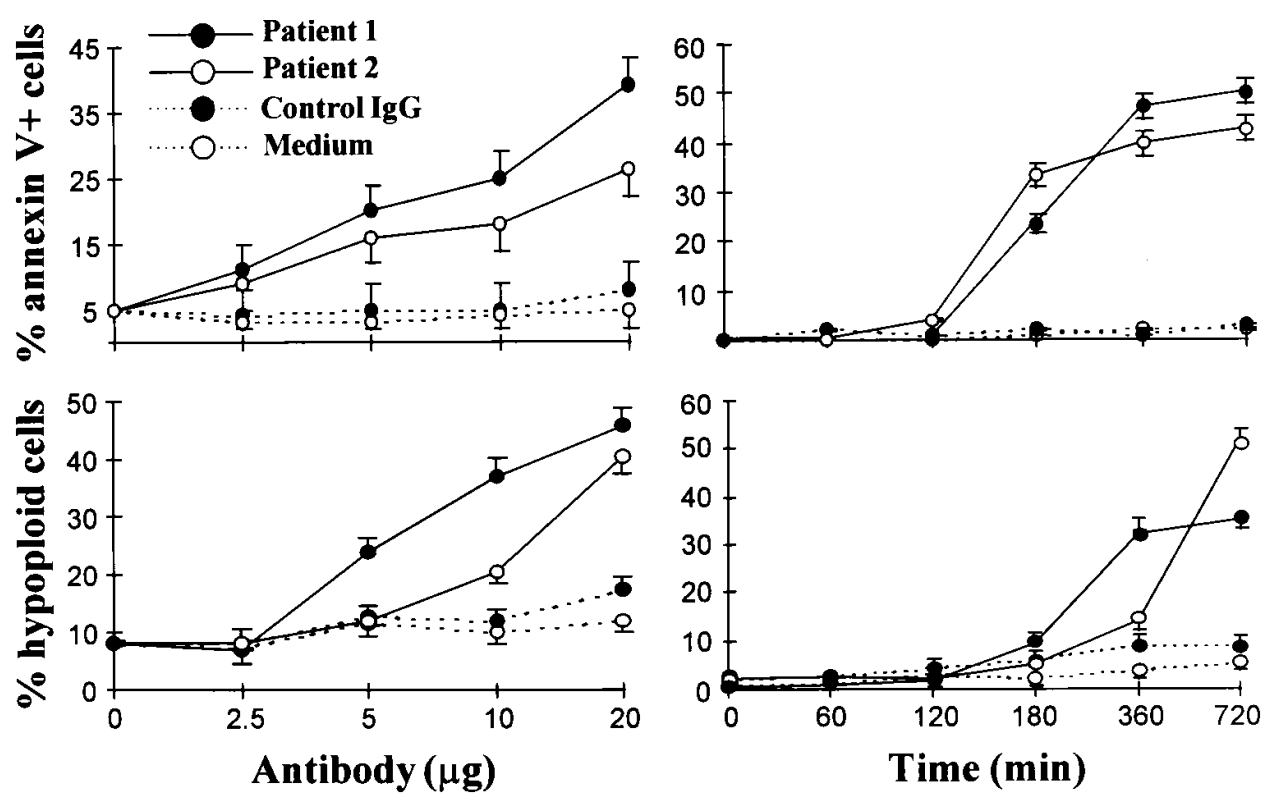

Figure 1. Dose effect (left) and time course (right) analyses of anionic phospholipid exposure (top) and hypoploid cell appearance (bottom) after incubation of EC with anti-EC Ab from two patients with SS.

apoptosis may be induced via CD77. 18 AECA-negative sera (3 with aPL, 4 with double-stranded DNA Ab, 4 with antiRNP Ab, and 7 with rheumatoid factor) did not induce the binding of annexin $\mathrm{V}$ to EC. The accelerated apoptosis was not unique to the SS vasculitis. Albeit more frequent $(P<0.04)$ in SS than in other diseases (Table III), apoptosis-inducing AECA appeared to be present in some patients with a variety of conditions associated with vasculitis.

To exclude the possibility that $\mathrm{IgG} / \mathrm{Fcy} \mathrm{R}$ interaction was involved in this induction, AECA-negative patient sera, normal human sera, and aggregated human and rabbit IgG were also tested. None of these induced significant changes in membrane PL. A minor subset of EC carried Fcy R: the percentages of cells expressing Fcy RI (CD64), Fc $\gamma$ RII (CD32), and Fcy RIII (CD16) were 6.6, 8.6, and 7.3\%, respectively. The results obtained with IgG AECA and $\mathrm{F}\left(\mathrm{ab}^{\prime}\right)_{2}$ AECA from five patients were not significantly different (data not shown).

Dose effect and time course analyses. Fig. 1 shows that the expression of anionic PL was dependent on the dose of AECA (patients 1 and 2). Control human $\mathrm{IgG}$ at the same dose and medium failed to increase anionic PL expression after a 360min incubation.

A time-course study revealed that the proportion of anionic PL-expressing cells correlated with the duration of the incubation of HUVEC with $20 \mu \mathrm{g}$ AECA. Triplicate measurements for each experimental point showed a variation of $<10 \%$. The time taken to reach maximal expression of anionic PL was $360 \mathrm{~min}$ and the results were broadly similar for the two SS patients tested. This expression was not different when the cells were treated for 720 min with control IgG and medium.

Relationships with apoptosis. The redistribution of plasma membrane PS preceded other events associated with apoptosis (22). As shown in Fig. 1, EC became annexin V positive before they became hypoploid, i.e., apoptotic. A period of $360 \mathrm{~min}$ was required for this to occur. Time-course analysis showed that the increase of annexin V-positive cells plateaued by 360 min, whereas less than half of these cells were hypoploid at this time. A representative example is shown in Fig. 2 (control human IgG and AECA IgG derived from patient 1).

Next, we examined whether the binding of AECA to EC was an absolute prerequisite for the externalization of PS. Exposure of PS and subsequent binding to annexin V by EC was induced only by AECA from six of the eight patients with SS (patients 1, 2, 3, 4, 5, and 8, but not patients 6 or 7). Fig. 3 shows the effect of AECA from patient 1 (79\% positive). In contrast, that of AECA from patient 7 was negligible (15\% positive) and close to levels reached by the controls.

Apoptosis measured by DNA fragmentation, morphology,

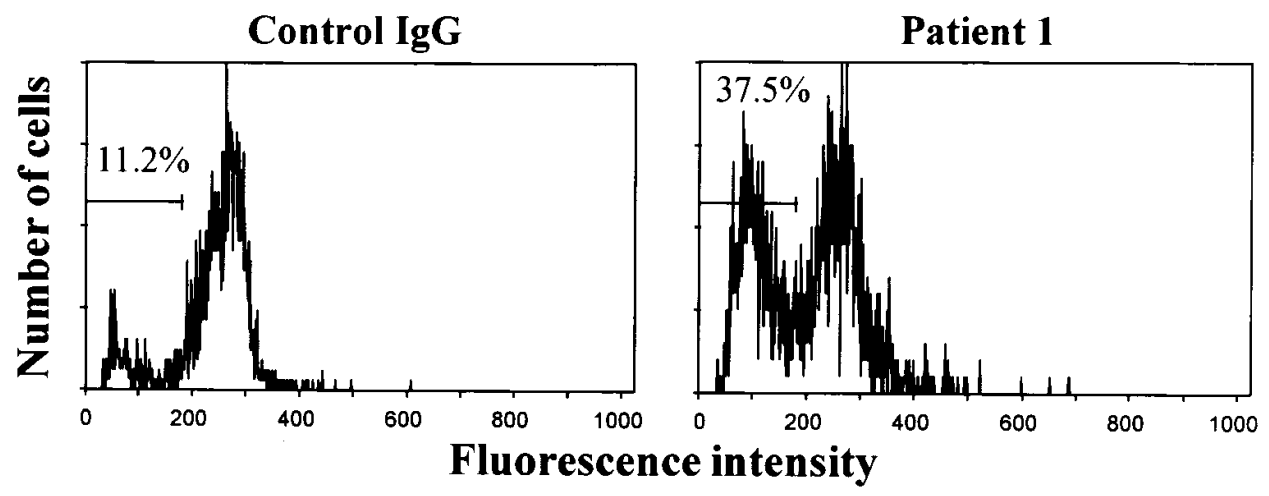

Figure 2. A representative example of hypoploid EC after incubation with anti-EC antibodies from patient 1 with SS. 


\section{Control IgG}
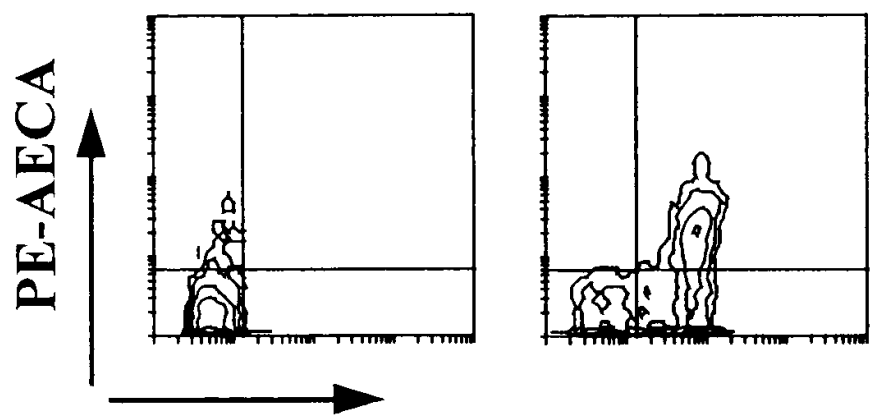

FITC-annexin V

and electron microscopy. To confirm apoptosis, DNA fragmentation and cell morphology studies were carried out. DNA showed fragmentation (Fig. 4, lane 3). May-Grünwald-Giemsastained EC from the same cultures showed apoptotic morphology (Fig. 5, top) and this was confirmed by ultrastructural anal-

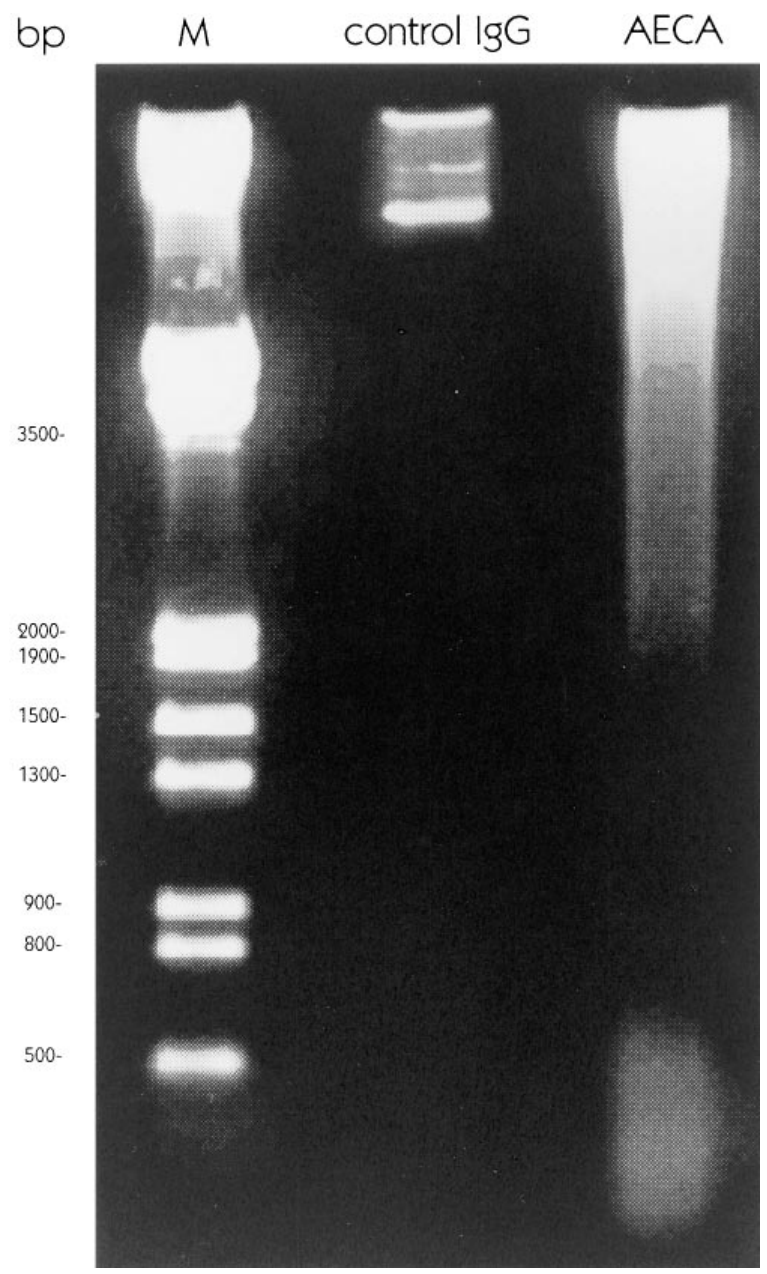

Figure 4. Agarose gel electrophoresis showing DNA degradation of endothelial cells (lane 1, size markers; lane 2, cells incubated with control IgG; and lane 3, cells incubated with autoantibodies from patient 1$)$.

\section{Patient 7}

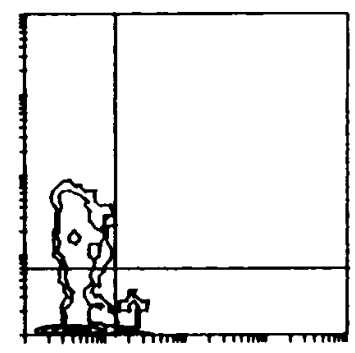

Figure 3. The accessibility of PS to annexin $\mathrm{V}$ is restricted to those EC modified by anti-EC Ab from patient 1 , while the auto $\mathrm{Ab}$ from patient 7 has no effects.

ysis (Fig. 5, bottom). Here, the nuclear changes characteristic of apoptosis (restriction of the size and production of apoptotic bodies) were observed. Thus, the exposure of plasma membrane PS and the uptake of PI, after incubation of HUVEC with AECA, were the results of induction of apoptosis, rather than the consequence of cellular injury and necrosis.

Characterization of apoptosis-inducing AECA. Since we were aware that aPL bind to apoptotic cells and may induce apoptosis, the sera were carefully absorbed with CL, although they had been selected as being aPL-negative. This absorption

Control lg $G$
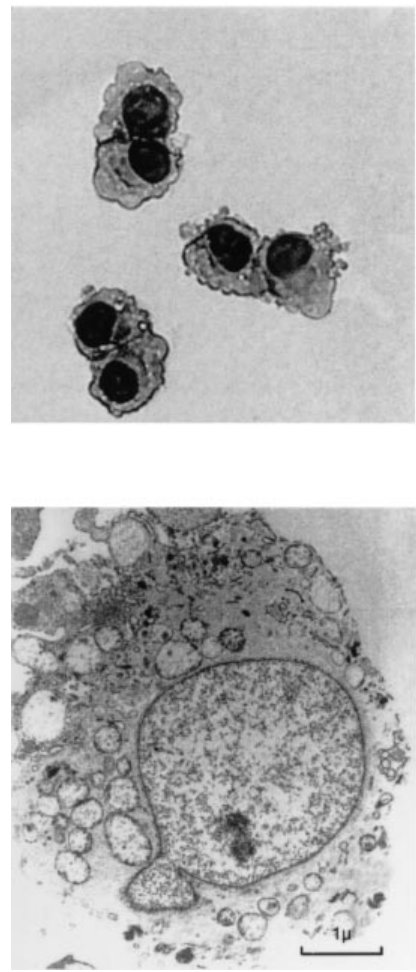

AECA
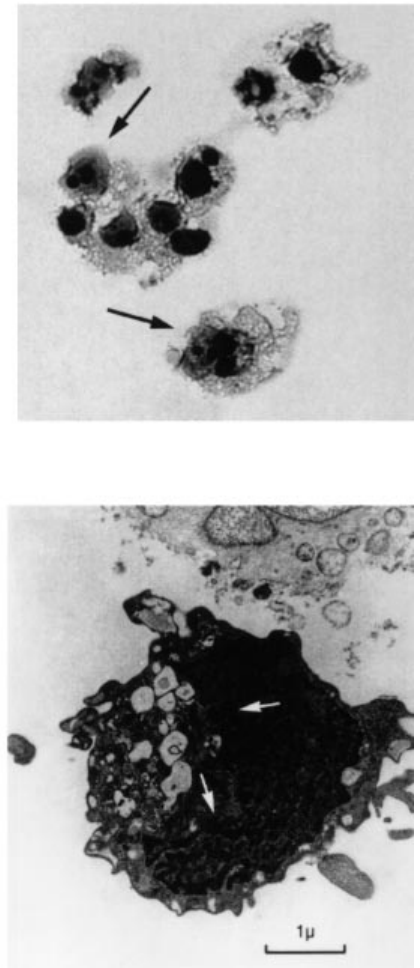

Figure 5. Cells stained with May-Grünwald-Giemsa (top) exhibit a typical morphology of apoptosis (arrows). Ultrastructural study of these cells (bottom) shows fragmentation into apoptotic bodies (arrows). 
Table IV. $\beta_{2} G P I, \beta_{2} G P I$-dependent aPL, and $\beta_{2} G P I$ independent aPL in sera passed through a CL column and eluted from a protein $G$ column

\begin{tabular}{|c|c|c|c|c|c|c|}
\hline \multirow[b]{2}{*}{$\begin{array}{l}\text { SS } \\
\text { patients }\end{array}$} & \multicolumn{3}{|c|}{ Effluents from the CL column } & \multicolumn{3}{|c|}{$\begin{array}{l}\text { Eluates from the protein } \mathrm{G} \\
\text { column }\end{array}$} \\
\hline & $\beta_{2} \mathrm{GPI}$ & $\begin{array}{c}\beta_{2} \mathrm{GPI}- \\
\text { depen- } \\
\text { dent aPL }\end{array}$ & $\begin{array}{l}\beta_{2} \mathrm{GPI}- \\
\text { indepen- } \\
\text { dent aPL }\end{array}$ & $\beta_{2} \mathrm{GPI}$ & $\begin{array}{c}\beta_{2} \text { GPI- } \\
\text { depen- } \\
\text { dent aPL }\end{array}$ & $\begin{array}{l}\beta_{2} \text { GPI- } \\
\text { indepen- } \\
\text { dent aPL }\end{array}$ \\
\hline 1 & $1.6 *$ & $0.100^{\ddagger}$ & 0.054 & 0.1 & 0.087 & 0.041 \\
\hline 2 & 1.8 & 0.097 & 0.084 & 0.4 & 0.090 & 0.072 \\
\hline 3 & 1.9 & 0.080 & 0.050 & 0.3 & 0.042 & 0.091 \\
\hline 4 & 2.5 & 0.040 & 0.082 & 0.5 & 0.054 & 0.067 \\
\hline 5 & 1.6 & 0.102 & 0.087 & 0.5 & 0.099 & 0.090 \\
\hline 6 & 2.0 & 0.095 & 0.081 & 0.3 & 0.102 & 0.084 \\
\hline 7 & 1.7 & 0.042 & 0.053 & 0.2 & 0.050 & 0.057 \\
\hline 8 & 2.2 & 0.091 & 0.046 & 0.1 & 0.040 & 0.033 \\
\hline
\end{tabular}

$* \mathrm{ng} / \mathrm{ml} ;{ }^{\ddagger} \mathrm{OD}$.

was successful, since $\beta_{2}$ GPI, $\beta_{2}$ GPI-dependent aPL, and $\beta_{2}$ GPI-independent aPL were not detectable in the effluents 1-8 from the CL column and in the eluates $1-8$ from the protein G column (Table IV).

Then, we asked whether the target Ag of the apoptosisinducing AECA was associated with the Fas receptor. Initial experiments determined that $3.2 \%$ of HUVEC (MFI:1.61) expressed the Fas receptor. It has been reported that IFN $\gamma$ can increase Fas expression in EC (23) and indeed $100 \mathrm{U} / \mathrm{ml}$ IFNy caused a reproducible but small increase in Fas $(12.7 \%$, MFI: 1.35 after a $24-\mathrm{h}$ incubation; and 21.4\%, MFI:2.16 after a 48-h incubation). After incubation with $5 \mu \mathrm{g} / \mathrm{ml} \mathrm{CH} 11$ (this anti-Fas $\mathrm{mAb}$ is known to trigger apoptosis), as few as $9.7 \%$ of EC became annexin $\mathrm{V}$ positive. Furthermore, a 2-h preincubation of EC with $5 \mu \mathrm{g} / \mathrm{ml} \mathrm{ZB} 4$, which is an anti-Fas mAb known to inhibit Fas-induced apoptosis (24), did not prevent the AECAinduced apoptosis: 29.7 and $30.1 \%$ EC became annexin V positive after a 4-h incubation with affinity-purified IgG AECA from patient 1 and patient 2 , respectively.

\section{Discussion}

A number of studies have suggested that EC injury results in an altered distribution of surface $\mathrm{Ag}$ and promotes active binding of immune complexes to these cells. For example, Herpes simplex virus induces the expression of $\mathrm{Fcy}$ and $\mathrm{C} 3 \mathrm{re}-$ ceptors on cultured EC (25). In patients with systemic diseases, there is indirect evidence of EC activation, including raised plasma levels of vWf (26) and TM (27). However, the pathogenic role of AECA remains unclear, inasmuch as the EC activation does not necessarily imply that the membrane PL asymmetry is modified by these autoAb.

In this paper, we demonstrate that AECA from some, but not all, patients with SS (i.e., a subset of these autoAb) is one of many factors potentially responsible for PS reaching the surface from its intracellular location, which is a prerequisite to apoptosis. Importantly, only some of the patients with SS had the PS exposure-inducing subset of AECA. These autoAb might be useful markers of the disease, since the six positive SS patients had been classified previously as having a diffuse form of the disease, while the two negative patients had a limited form of the same disorder (7). However, the accelerated apoptosis was not absolutely specific for SS. Although significantly more frequent in diffuse SS than in other conditions, apoptosis-inducing AECA appeared to be present in some patients with a variety of connective tissue diseases associated with vasculitis.

The uptake of PI was not due to cellular necrosis since EC exhibited typical apoptotic morphology and DNA appeared to be fragmented. Furthermore, this phenomenon was AECAspecific, given that seven control xenotropic $\mathrm{mAb}$ and various autoAb had no effects. That $\mathrm{IgG} / \mathrm{Fc} \gamma \mathrm{R}$ interaction was involved in the binding of AECA is unlikely, since $\mathrm{mAb}$ directed towards EC membrane determinants, normal sera, and aggregated IgG failed to modify the PL asymmetry. Furthermore, Fc $\gamma$ Rs are expressed constitutively by placental villous EC (28), but weakly by HUVEC (29). The effect was not distinguishably different when $\mathrm{F}\left(\mathrm{ab}^{\prime}\right)_{2}$ fragments were used instead of IgG AECA.

In a previous study (19) using the human EC line, EA.hy 926, we detected deposition of $\beta_{2}$ GPI on GTA-fixed cells, but not at all on fresh unfixed cells. Consistent with this observation, Del Papa et al. (30) have also reported that EC membrane alteration induced by paraformaldehyde fixation enhances the binding of affinity-purified AECA preparations. Hence, EC activation is not sufficient per se to cause the loss of asymmetry of PL.

Of particular relevance to our study, Sgonc et al. (6) have provided convincing evidence that apoptosis of EC is a triggering event in the pathogenesis of avian and human SS. Our study establishes that induction of this programmed cell death can, at least in some patients, be mediated by a subset of AECA and preceded by anionic PL exposure. We have shown that EC become annexin $\mathrm{V}$ positive before becoming hypoploid, and provide clear evidence that AECA binding induces apoptosis of EC. A major concern is the specificity of the autoAb used in our study. AECA did not react with the Fas receptor, because preincubation of the cells with $\mathrm{ZB} 4$, which is a $\mathrm{mAb}$ shown to inhibit Fas-induced apoptosis (24), did not reduce apoptosis due to AECA. This observation is in agreement with the report that Fas ligation does not trigger apoptosis in EC (23). In this respect, we have demonstrated recently (Levy, Y., B. Gilburg, J. George, N. Del Papa, R. Mallone, M. Damianovich, M. Blank, A. Radice, Y. Renaudineau, P. Youinou, A. Wiik, F. Malasavi, P.L. Meroni, and Y. Schoenfeld, manuscript submitted for publication) that an apoptosisinducing mouse monoclonal AECA recognizes a $70-\mathrm{kD}$ molecule. This unknown protein might represent a critical target for apoptosis-inducing AECA. Other EC molecules recognized by AECA from patients $1,2,3,4,5$, and 8 are likely to be involved in apoptosis of EC. Yet, the Ag recognized by apoptosis-inducing AECA are as yet unknown. Immunoblotting techniques have been used for some time to identify the target $\mathrm{Ag}$ of AECA, but with considerable variation in the results obtained. One group found 11 proteins ranging in size from 56 to $133 \mathrm{kD}$, a second described two bands of 60 and $62 \mathrm{kD}$, and a third group identified 12 proteins ranging from 16 to $88 \mathrm{kD}$ (for review see reference 3 ).

In conclusion, the work described here establishes the ability of AECA from some patients with SS and, to a far lesser degree from other patients, to bind to fresh EC and initiate 
apoptosis that is preceded by the exposure of PS. Since independent preliminary data $(31,32)$ indicate that aPL bind to apoptotic cells, our findings contribute to the opening of a new field for investigation (Bordron, A., M. Dueymes, Y. Levy, C. Jamin, L. Ziporen, J.C. Piette, Y. Shoenfeld, and P. Youinou, manuscript submitted for publication). Studies are in progress to identify the cell surface epitope(s) that apoptosis-inducing AECA recognize. Further analysis of human monoclonal AECA with apoptosis-inducing activity should provide a fruitful approach to Ag identification.

\section{Acknowledgments}

We are indebted to Dr. Chris P.M. Reutelingsperger (Maastricht, The Netherlands), Dr. Josiane Arvieux (Grenoble, France), Dr. Marie-Claire Boffa (Paris), and Professor Steven A. Krilis (Sydney, Australia) for the generous donation of reagents, and to Dr. JeanJacques Chabaud and Dr. Hubert Le Bos (Brest, France) for their help in collecting umbilical cords. Thanks are due to Professors Ivan M. Roitt and Peter M. Lydyard (London) for very helpful comments. The expert and cheerful secretarial assistance of Mrs. Simone Forest and Pacale Hélary is appreciated.

A. Bordron is a recipient of a fellowship from the Communauté Urbaine de Brest, France.

\section{References}

1. Cines, D.B., A.P. Lyss, M. Reeber, M. Bina, and R.J. DeHoratius. 1984. Presence of complement-fixing antiendothelial cell antibodies in systemic lupus erythematosus. J. Clin. Invest. 73:611-625.

2. Meroni, P.L., and P. Youinou. 1996. Endothelial cell antibodies. In Autoantibodies. J.B. Peter and Y. Shoenfeld, editors. Elsevier Science B.V., Amsterdam. 245-252.

3. Youinou, P., P.L. Meroni, M.A. Khamashta, and Y. Shoenfeld. 1995. A need for standardization of the antiendothelial cell antibody test. Immunol. Today. 16:363-364.

4. Salojin, K.V., M. Le Tonquèze, E.L. Nassonov, M.T. Blouch, A.A. Baranov, A. Saraux, L. Guillevin, J.N. Fiessinger, J.C. Piette, and P. Youinou. 1996. Antiendothelial cell antibodies in patients with various forms of vasculitis. Clin. Exp. Rheumatol. 14:163-169.

5. Meroni, P.L. 1997. What is going to happen tomorrow in the field of antiendothelial cell autoantibodies related to vasculitis? Ann. Med. Interne. 145: 467-468.

6. Sgonc, R., M.S. Gruschwitz, H. Dietrich, H. Recheis, M.E. Gershwin, and G. Wick. 1996. Endothelial cell apoptosis is a primary pathogenetic event underlying skin lesions in avian and human scleroderma. J. Clin. Invest. 98:785-792.

7. Salojin, K.V., M. Le Tonquèze, A. Saraux, M. Dueymes, E.L. Nassonov, J.C. Piette, and P. Youinou. 1997. Antiendothelial cell activity: a useful marker of endothelial damage in systemic sclerosis. Am. J. Med. 102:178-185.

8. Fadok, V.A., D.R. Voelker, P.A. Campbell, J.J. Cohen, D.L. Bratton, and P.M. Henson. 1992. Exposure of phosphatidylserine on the surface of apoptotic lymphocytes triggers specific recognition and removal by macrophages. $J$. Immunol. 148:2207-2215.

9. Andree, H.A.M., C.P.M. Reutelingsperger, R. Haupman, H.C. Hembker, W. Th. Hermens, and G.M. Willems. 1990. Binding of vascular anticoagulant $\alpha$ to plasma phospholipid bilayers. J. Biol. Chem. 265:4923-4929.

10. Del Papa, N., L. Guidali, M. Sironi, Y. Shoenfeld, A. Mantovani, A. Tincani, G. Balestrieri, A. Radice, A. Sinico, and P.L. Meroni. 1996. Antiendothelial cell IgG antibodies from patients with Wegener's granulomatosis bind to human endothelial cells in vitro and induce adhesion molecule expression and cytokine secretion. Arthritis Rheum. 39:758-766.

11. Carvalho, D., C.O.S. Savage, C.M. Black, and J.D. Pearson. 1996. IgG antiendothelial cell autoantibodies from scleroderma patients induce leukocyte adhesion to human vascular endothelial cells in vitro. J. Clin. Invest. 97:111-119.

12. Masi, A.T., G.P. Rodnan, T.A. Jr. Medsger, R.D. Altman, W.A. D'Angelo, A.R. Fries, E.C. Leroy, A.B. Kirsner, A.H. Mackenzie, D.J. McShare, et al. 1980. Preliminary criteria for the classification of systemic sclerosis (scleroderma). Arthritis Rheum. 25:581-590.

13. Hunder, G.G., D.A. Bloch, B.A. Michel, M.B. Stevens, W.P. Arend, L.H. Calabrese, S.M. Edworthy, A.S. Fauci, R.Y. Leavitt, J.T. Lie, et al. 1990. The American College of Rheumatology 1990 criteria for the classification of giant cell arteritis. Arthritis Rheum. 33:1122-1128.

14. Lightfoot, R.W., Jr., B.A. Michel, D.A. Bloch, G.G. Hunder, N.J. Zvaifler, D.J. McShane, W.P. Arend, L.H. Calabrese, R.Y. Leavitt, J.T. Lie, A.T. Masi, et al. 1990. The American College of Rheumatology 1990 criteria for the classification of polyarteritis nodosa. Arthritis Rheum. 33:1088-1093.

15. Arend, W.P., B.A. Michel, D.A. Bloch, G.G. Hunder, L.H. Calabrese, S.M. Edworthy, A.S. Fauci, R.Y. Leavitt, J.T. Lie, R.W. Lightfoot, Jr., et al. 1990. The American College of Rheumatology 1990 criteria for the classification of Takayasu arteritis. Arthritis Rheum. 33:1129-1134.

16. Leavitt, R.Y., A.S. Fauci, D.A. Bloch, B.A. Michel, G.G. Hunder, W.P. Arend, L.H. Calabrese, J.F. Fries, J.T. Lie, R.W. Lightfoot, Jr., et al. 1990. The American College of Rheumatology 1990 criteria for the classification of Wegener's granulomatosis. Arthritis Rheum. 33:1101-1107.

17. Tan, E.M., A.S. Cohen, J.F. Fries, A.T. Masi, D.J. McShane, N.F. Rothfield, J. Green Schaller, N. Talal, and R.J. Winchester. 1982. The 1982 revised criteria for the classification of systemic lupus erythematosus. Arthritis Rheum. 25:1271-1277.

18. Jaffe, E.A., R.I. Nachman, C.G. Becker, and C.R. Minick. 1973. Culture of human endothelial cells derived from umbilical veins. Identification by morphologic and immunologic criteria. J. Clin. Invest. 52:2745-2756.

19. Le Tonquèze, M., K.V. Salojin, M. Dueymes, J.C. Piette, V. Kovalev, Y. Shoenfeld, E.L. Nassonov, and P. Youinou. 1995. Role of $\beta 2$-glycoprotein I in the antiphospholipid antibody binding to endothelial cells. Lupus. 4:179-186.

20. Nicoletti, I., G. Migliorati, M.C. Pagliacci, F. Grignani, and C. Riccardi. 1991. A rapid and simple method for measuring thymocyte apoptosis by propidium iodide and flow cytometry. J. Immunol. Methods. 139:271-279.

21. Mangeney, M., C.A. Lingwood, S. Taga, B. Caillou, T. Tursz, and J. Wiels. 1993. Apoptosis induced in Burkitt's lymphoma cells via gb3/CD77, a glycolipid antigen. Cancer Res. 53:5314-5319.

22. Martin, S.J., C.P.M. Reutelingsperger, A.J. McGahon, J.A. Rader, R.C.A.A. van Schie, D.M. La Face, and D.R. Green. 1995. Early redistribution of plasma membrane phosphatidylserine is a general feature of apoptosis regardless of the initiating stimulus: inhibition by overexpression of $\mathrm{Bcl}-2$ and Abl.J. Exp. Med. 1982:1545-1556.

23. Richarson, B.C., N.D. Lalwani, K.J. Johnson, and R.M. Marks. 1994 Fas ligation triggers apopotosis in macrophages but not endothelial cells. Eur. J. Immunol. 24:2640-2645.

24. Yonehara, S., Y. Nishimura, S. Kishil, M. Yonehara, K. Takazawa, T. Tamatani, and A. Ishii. 1994. Involvement of apoptosis antigen Fas in clonal deletion of human thymocytes. Int. Immunol. 6:1849-1856.

25. Cines, D.B., A.P. Lyss, M. Bina, R. Corkey, N.A. Kefalides, and H.M. Friedman. 1984. Fc and C3 receptors induced by Herpes simplex virus on cultured endothelial cells. J. Clin. Invest. 69:123-128.

26. Lindsey, N.J., R.A. Dawson, F.I. Henderson, M. Greaves, and P. Hughes. 1993. Stimulation of von Willebrand factor antigen release by immunoglobulin from thrombosis prone patients with systemic lupus erythematosus and the antiphopholipid syndrome. Brit. J. Rheumatol. 32:123-126.

27. Boehme, M.W.J., W.H. Schmitt, P. Youinou, W. Stremmel, and W.L. Gross. 1996. Clinical relevance of elevated thrombomodulin and soluble E-selectin in patients with Wegener's granulomatosis and other systemic vasculitis. Am. J. Med. 101: 387-394.

28. Sedmak, D.D., D.H. Davis, U. Singh, J.G.J. van de Winkel, and C.L. Anderson. 1991. Expression of IgG Fc receptor antigens in placenta and on endothelial cells in humans. Am. J. Pathol. 138:175-181.

29. Le Tonquèze, M., C. Jamin, M. Boehme, R. Le Corre, M. Dueymes, and P. Youinou. 1996. Establishment and characterization of permanent endothelial cell clones. Analysis of cell surface molecule expression and shedding. $\mathrm{Lu}$ pus. 5:103-112.

30. Del Papa, N., L. Guidali, L. Spatola, P. Bonara, M.O. Borghi, A. Tincani, G. Balestrieri, and P.L. Meroni. 1995. Relationship between antiphospholipid and antiendothelial cell antibodies. III. $\beta 2$-glycoprotein I mediates the antibody binding to endothelial membranes and induces the expression of adhesion molecules. Clin. Exp. Rheumatol. 13:179-185.

31. Goldman, D., G. Philips, K. Back, and M. Petri. 1995. Binding of SLE antibodies on apoptotic cells. Arthritis Rheum. 38(Suppl.):S214 (Abstr.)

32. Rosen, A., M. Schlissel, M. Petri, and L. Casciola-Rosen. 1995. Antiphospholipid antibodies bind to the surface of apoptotic cells and abolish their procoagulant activity. Arthritis Rheum. 38(Suppl.):S267 (Abstr.). 